Zagadnienia Rodzajów Literackich, LX, z. 3

PL ISSN 0084-4446

DOI: 10.26485/ZRL/2017/60.3/4

Joanna MaJ

Uniwersytet Wrocławski*

\title{
Muzealna historia literatury
}

\author{
Museum Literary History
}

\begin{abstract}
The article presents theoretical problems connected with museum literary history. It shows how the multimedia and interactive elements of exhibiting space change the so-called traditional communication about literary past. The author deliberates on the construction of literary and historical transmission to so-called variety of responders - not only the experts and academics. As the examples of the phenomenon she analyses Muzeum Pana Tadeusza in Wroclaw and Literaturmuseum der Österreichischen Nationalbibliothek in Vienna.
\end{abstract}


* Instytut Filologii Polskiej Uniwersytetu Wrocławskiego plac Nankiera 15, 50-996 Wrocław

e-mail: maj.joanna@gmail.com 
Muzeum literackie ${ }^{1}$ może stanowić formę historiografii literatury otwierającą opowieść o literackich dziejach na pozaakademickie audytorium, formę, która ze względu na sposób reprezentowania tego, co minione, dociera poza wyspecjalizowane grono odbiorców. Historia literatury jako muzeum zapożycza narzędzia narracyjne właściwe dla przestrzeni ekspozycyjnych oraz wydarzeń inicjowanych przez instytucję, której głównym wymiarem nie jest już dziś zbieranie i gromadzenie (Folga-Januszewska 2008: 2000) dokumentów literackich, rękopisów, pamiątek po twórcach i ikonograficznych przekazów związanych z literatura (Głowiński 2002: 328) (vide literackie muzeum modernistyczne, muzeum-swiecka śniqtynia), ale która współtworzy kulturę, generuje nie jedną, ale szereg opowieści o literaturze, nie ukrywa też tożsamościowych czy politycznych znamion swoich działań. Rola muzeum (literackiego) - masowej instytucji komunikowania o literaturze, a tym samym o pamięci, kulturze i tożsamości danej wspólnoty lub wspólnot — zmieniła się nie tylko ze względu na przemiany technologiczne i cywilizacyjne wpływające na możliwość udostępniania oraz percepcji dziedzictwa kulturowego (vide cyfryzacja, multimedialność eksposycji, wirtualność); choć to demokratyzacja komunikacji w jego obrębie oraz wpływ idei tzw. kultury uczestnictwa sprawily, że odmiennie wyzyskano jego potencjal jako kolekcji-kłącza.

Nie każde muzeum literackie stanowi formę historii literatury. Jak zauważa Magdalena Lachman, nazwa ta charakteryzuje się dużą pojemnością semantyczną, „obejmuje swoim zakresem muzea biograficzne, domy-muzea czy izby pamięci poświęcone konkretnym pisarzom (...), odnosi się również do instytucji o bardziej ogólnym charakterze, dopracowujących się muzealnych sposobów eksponowania literatury z uwzględnieniem podstawowych dla niej kontekstów (w Polsce najważniejsza rola przypada Muzeum Literatury im. Adama Mickiewicza w Warszawie)" (Lachman 2006: 346-347). Badaczka przyznaje również, że „,nie ma zgody, czy istota muzeum literackiego zasadza się przede wszystkim

1 Muzeum literackie nie jest nowym zjawiskiem na mapie kultury, jednak jego nowa, aktualna forma wynika z tendencji obecnych we współczesnej humanistyce. Kluczową rolę odgrywa tu stale wzrastająca dominacja wizualności nad oralnością oraz pismem, a także uprzywilejowana pozycja tzw. nowych mediów. Muzeum multimedialne, interaktywne to szeroko dyskutowane zagadnienie, moje zainteresowania koncentrują się na problemie relacji materialność-niematerialność w muzealnej historii literatury. Muzeum traktuję jako formę przekładu z języka akademickiego na popularny dyskurs historyczny. Zajmuja mnie jego możliwości popularyzatorskie oraz funkcje i znaczenia we współczesnej kulturze. 
na wystawiennictwie i popularyzacji literatury (czyli pośrednio na stymulowaniu życia artystycznego), czy też na ściśle fachowym podejściu do zbiorów, ich katalogowaniu, opracowaniu”, udostępnianiu (2006: 347).

Przyglądając się więc muzeum literackiemu jako możliwej formie historii literatury, analizuję tylko przypadki multimedialne, które (w całości lub w wybranej części wystawienniczej) uznać można za rodzaj historiografii literatury. Oznacza to, że przedmiotem moich badań są nie muzea literackie, które monografizują wybrane zjawisko (np. traktują o biografii lub twórczości wybranego pisarza, jak Pawilon Józefa Czapskiego w Krakowie, Muzeum Ignacego Kraszewskiego w Dreźnie; lub dotyczą działalności wybranej grupy artystycznej), ale te, które proponują spojrzenie na pewną serię wybranych wydarzeń literackich, tzn. uruchamiaja perspektywę historycznoliteracką ${ }^{2}$. Moja analiza ma charakter case study, co nie znaczy, że nie można znaleźć innych przykładów podobnego konstruowania narracji muzealnej ${ }^{3}$.

Muzeum — stanowiące dziś jedno z centralnych form postnowoczesnej kultury konstruuje historię literatury, używając multimedialnych oraz performatywnych środków, nie zarzuca jednak materialności na rzecz totalnej cyfrowości w obrębie historycznoliterackich wystaw. Materialność stanowi bowiem podstawę funkcjonowania literackiego muzeum ze względu na - przedłużaną i akcentowaną poprzez rozwijanie opowieści towarzyszącej eksponatom - auratyczność prezentowanych obiektów ${ }^{4}$. Takim typem muzealnej opowieści o literackiej przeszłości posługuja się m.in. Muzeum Pana Tadeusza we Wrocławiu oraz Literaturmuseum der Österreichischen Nationalbibliothek [Muzeum Literatury Austriackiej Biblioteki Narodowej] w Wiedniu. Pierwsze z nich, konstruując narrację wokół głównego piśmienniczego zabytku — rękopisu poematu Adama Mickiewicza, opowiada historię polskiego romantyzmu jako epoki oraz prezentuje ideę romantyzmu w perspektywie długiego trwania ${ }^{5}$; drugie, próbując odpowiedzieć na pytania dotyczące statusu austriackiej literatury i kultury (Was ist ein literarisches Museum? Was ist Österreich? Was ist Literatur? [Czym jest literackie muzeum? Co oznacza Austria? Czym jest literatura?] ${ }^{6}$ ), ucieka się do prezentacji tematycznej i chronologicznej austriackiej literackiej przeszłości od końca XVIII wieku po współczesność. Pod kątem konstrukcyjnym i metodologicznym

2 Omawiane przeze mnie instytucje, stanowiące egzemplifikację zjawiska, jakim jest muzealna historia literatury, dobrałam według klucza przyległości. Istotną rolę odgrywała dla mnie obecność nowych mediów w opisywanej przestrzeni muzealnej, jednak zależało mi też na tym, by wybrane muzea nie odrzucały klasycznej formy opowieści stawiającej w centrum eksponat.

3 Podobną perspektywę historycznoliterackiej opowieści stwarzało np. działające w latach 1958-1983 Museum für sorbische Literatur und Schrifttum im Haus der Sorben [Muzeum serbołużuckiej literatury i piśmiennictwa w Domu Serbołużyckim] w Budziszynie, jednak nie nowe media odgrywały kluczową rolę w tej narracji. Ciekawym przypadkiem wydaje się też Museum für Westfälisches Literatur [Muzeum Literatury Westfalskiej] stanowiące część instytucji, jaką jest Kulturguts Haus Nottbeck. Muzeum to opowieść o literaturze danej epoki wiąże z mediami jej czasów. O westfalskim oświeceniu i romantyzmie znaleźć można jedynie tablice informacyjne z tekstem, replikami obrazów, do nich zaś dołączają eksponaty w postaci książek drukowanych w XVIII i XIX wieku, zaś o literaturze powstającej w Westfalii w wieku XX i XXI mówi się już przy użyciu nagranego dźwięku, bądź multimedialnych ekranów.

$4 \quad$ Na temat auratyczności dzieła vide Benjamin 1996 oraz Kostyrko 2006.

5 Sale poświęcone aktualności Pana Tadeusza dziś, sale dotyczące twórczości Andrzeja Wajdy oraz biografii Władysława Bartoszewskiego i Jana Nowaka-Jeziorańskiego.

6 Trzy pytania stanowiące podstawę programową muzeum (Schweiger 2016). 
oba muzea stanowią zarazem materialną (auratyczna) historię literatury, historię literatury audialną i wizualna, a także performatywną — te różne sposoby mówienia o przeszłości tworzą muzealną historię literatury.

Współczesne muzeum literackie zbiera heterogeniczne formy komunikacji, formy prezentowania literackich dziejów. Umożliwia przekład historii literatury z języka profesjonalnego, z idiolektu badań naukowych na niespecjalistyczny język — muzealny — pozwala na popularyzację wiedzy o literackich dziejach, stwarza szansę na polityczne i etyczne oddziaływanie przekazu historycznoliterackiego poza eksperckim gronem. Historia literatury — rozumiana potocznie, jak stwierdza Teresa Walas — bywa zazwyczaj „mieszaniną bibliografii, biografistyki, historii form literackich, historii politycznej i społecznej, dziejów idei oraz estetycznego wartościowania" (Walas 1993: 16). Wszystkie wymienione elementy obecne są w literackim muzeum, jednak ze względu na jego cechy genologiczne kształtują one komunikację dotyczącą literackiej przeszłości w sposób odmienny od tradycyjnych środków wykorzystywanych przez literaturoznawczą dyscyplinę (tu, by dookreślić: odmienny np. od syntezy historycznoliterackiej).

Robert A. Rosenstone w manifeście Space for the Bird to Fly określa sposoby wypowiedzi, po które — oprócz tradycyjnych — sięgać powinni/moga współcześni historycy tak, by ich praca recypowana była również poza akademią. Konstatuje on: „We must paint, write, film, dance, hip hop and rap the past in a way that makes the tragedies and joys of the human voyage meaningful to the contemporary world" [Musimy malować, pisać, filmować, tańczyć przeszłość, tworzyć o niej hip hop i rap w sposób, który uczyni tragedie i radości ludzkiej podróży znaczącym dla współczesnego świata] (Rosenstone 2007: 17). Rosenstone wymienia również kolaż, komiks, taniec, grafiki, gatunki detektywistyczne i romansowe lub serie e-maili jako potencjalne formy zrewolucjonizowanego opowiadania historii, które, odpowiadając aktualnym sposobom doświadczania kultury przez jej użytkowników, pozwalałyby rozumieć współczesny sens przeszłości; które niosłyby znaczenie nie tylko dla historyka, ale określałyby miejsce minionych dziejów we współczesnej kulturze (Rosenstone 2007: 18). Współczesne muzeum literackie i jego środki komunikacji wydają się przystawać do powyższych enumeracji.

\section{Materialność i nowe media w muzeum literackim}

Muzeum literackie w porównaniu z innymi instytucjami pośredniczącymi pomiędzy historią literatury a odbiorca, takimi jak szkoła, media drukowane czy (audio)wizualne — telewizja, film lub radio (Wehnert 2002: 68), stwarza możliwość bezpośredniego doświadczania przeszłości, a przynajmniej uczestniczących w niej rzeczy. Zbiera literackie eksponaty należące do literatów przedmioty: codziennego użytku i te przeznaczone do pracy (przybory piśmiennicze, papier, maszyna do pisania itd.), a także rękopisy, listy, fotografie, obrazy, książki, pamiątki, elementy garderoby, biżuterię itd. W niektórych przypadkach muzeum umożliwia przebywanie w miejscach, w których rodziła się, wydarzała się historia literatury (takich jak artystyczny salon, pracowania pisarza) lub też próbuje taką literacką przestrzeń zrekonstruować, odtworzyć za pomocą zachowanych artefaktów. Literaturmuseum der Österreichischen Nationalbibliothek znajduje się zaś w Grillparzerhaus, budynku stanowiącym dawną część Austriackiego Archiwum Narodowego - Hofkammerarchiv 
[Archiwum Izby Nadwornej]. Zachowano w jego przestrzeni zabytkowe, drewniane, osiemnastowieczne regały, na ich półkach ustawiono gabloty z eksponatami oraz wstawiono w nie uzupełniające narrację multimedia ${ }^{7}$.

Funkcja obiektów gromadzonych przez muzeum o profilu historycznoliterackim nie polega wyłącznie na ilustrowaniu czy upamiętnianiu literackich wydarzeń ${ }^{8}$. Rzeczy w przestrzeni wystawienniczej moga stanowić również podmioty — nie zaś przedmioty — narracji. Inspirowani zwrotem ku ržeczom twórcy katalogu Das Literaturmuseum. 101 Objekte und Gescbicbten [Muzeum literatury. 101 przedmiotów i historii] (Fetz 2015) proponują w ten sposób spoglądać na zbiory stałej ekspozycji Muzeum Literatury w Wiedniu. „Literatur ist auch, was nicht zwischen zwei Buchdeckel passt: Manuskripte, Fotos und Plakate, aber auch Filme, Töne und Objekte — das Literaturmuseum der Österreichischen Nationalbibliothek erfüllt Literaturgeschichte mit neuem Leben" "Literatura to także to, co nie mieści się pomiędzy dwiema okładkami książki: rękopisy, fotografie i plakaty, ale także filmy, dźwięki i przedmioty - Muzeum Literatury Austriackiej Biblioteki Narodowej wypełnia historię literatury nowym życiem] — deklarują autorzy, prezentując wybrane obiekty wraz z ich literacką historią. W Muzeum Pana Tadeusza wokół przedmiotu — oryginału, rękopisu dzieła — zbudowana jest zaś cała opowieść, pozostałe eksponaty umieszczane w witrynach pośród rekonstrukcji, kopii, stanowia jeden z wielu elementów historycznej narracji.

Bez względu na status i rolę w każdym ze wskazanych kontekstów głównym zadaniem obiektów muzealnych pozostaje stwarzanie odbiorcy możliwości „bezpośredniego" doświadczania przeszłości literackiej. Historia literatury opowiadana lub ilustrowana przez artefakty staje się historią dostępną bic et nunc w przestrzeni muzealnej. Materialność obiektu zaświadcza i przekonuje o prawdziwości towarzyszącej mu historycznoliterackiej narracji. Podobną funkcję unaoczniania, odtwarzania przeszłości wydają się pełnić kopie i rekonstrukcje, nie posiadają one jednak uroku autentyczności. Szczególne znaczenie maja jednak obiekty-oryginały. Prezentowane na wystawie literackiej — stwierdza Stefanie Wehnert - posiadają specyficzną siłę przyciagania ze względu na urok oryginalności aurę (Wehnert 2002: 88). Eksponaty-oryginały są bezpośrednim śladem przeszłości, nie są zapośredniczane przez żadne medium, ich dostępność, empiryczność stanowią potwierdzenie wydarzeń, o których zaświadczaja ${ }^{10}$. Wyrażają tęsknotę „za bezpośrednim dostępem do świata, oczyszczonego z zapośredniczeń” (Olsen 2010: 581). Materialność staje się argumentem na rzecz prawdziwości (re)prezentowanej historii literatury, zaspokaja głód „rzeczywistości”, którego spragniony jest użytkownik współczesnej — zdominowanej przez nowe media, cyfrowej — kultury.

Historia literatury konstruowana przez muzeum, bazując $\mathrm{w}$ znacznej mierze na bezpośredniej obecności eksponatów, które budują narrację (bistorie, biografie ręecsy) lub wokół których budowana jest narracja, włącza w swoją opowieść nowe media ${ }^{11}$. Stwarza w ten

7 Do muzeum przynależy też pokój pracy Franza Grillparzera, zaś w jednym z „rozdziałów” ekspozycji opowiedziana zostaje historia budynku, w którym mieści się wystawa.

8 Więcej o roli materialności w literackiej muzealnej przestrzeni vide Böhmer 2015.

9 Opis publikacji przygotowany przez wydawnictwo Jung und Jung omawiający katalog wystawy Literaturmuseum (Bücher. Bernhard Fetz. (Hrsg.) Das Literaturmuseum b.r.).

Choć wydaje się, że muzeum i przestrzeń wystawiennicza są pewnego rodzaju medium oraz tworzą interpretacyjną ramę.

11 Na temat nowych mediów w przestrzeni muzealnej vide Henning 2006. 
sposób zwiedzającemu możliwość różnorodnego doświadczania eksponatów, polisensorycznego odbioru prezentowanej przeszłości. Ze względu na to, że literackie pamiątki prezentowane sa zazwyczaj w gablotach, muzeum poszukuje nowych sposobów niwelowania wynikającego z zasad prezentacji dystansu pomiędzy przedmiotem a odbiorcą. Umożliwia więc poznanie odwiedzającym dodatkowo poprzez formy takie jak: ekran dotykowy, tablice interaktywne, hologramy (seria ekranów przedstawiających wynurzające się z mgły sylwetki postaci z epoki w Muzeum Pana Tadeusza), prezentacje dźwiękowe i wizualne (algorytm uruchamiający audialne nagranie rozdziału Pana Tadeusz̧a poświęconego szlacheckiemu zwyczajowi rodzinnego spacerowania reagujący na ruch w jeden z sal wrocławskiego muzeum), pokazy multimedialne, projekcje laserowe, zarządzanie oświetleniem, gry interaktywne (gra polegająca na dopasowaniu brakujących części do szkatuły służącej przechowywaniu rękopisu poematu Mickiewicza), filmy (film ukazujący poranną toaletę szlachcianki w Muzeum Pana Tadeusza), animacje. Środki te wykorzystywane są m.in. do prezentacji opisów towarzyszącym eksponatom, rozwinięcia narracji stwarzanej przez rzeczy, ukazania dodatkowych kontekstów wybranego przedmiotu lub jako osobny element wystawy.

Część informacji nie jest udostępniana zwiedzającym w przestrzeni muzealnej, ale można się z nimi zapoznać, używając wręczanych gościom urządzeń mobilnych (np. audioprzewodników czy przewodników multimedialnych umieszczonych na tabletach). W ten sposób uzyskać można szczegółowe informacje — dotyczące eksponatów, twórców literackich itd. — które nie znalazły się w głównej części wystawy. Uruchamiając odpowiednie fotokody lub hiperlinki, uzyskuje się dostęp do trójwymiarowych wizualizacji obiektów, materiałów dźwiękowych i filmowych ukazujących kontekst przedmiotu itd. Urządzenie mobilne rozdawane zwiedzającym stwarza też możliwość prowadzenia równoległych narracji w wielu językach — tak dzieje się w Muzeum Literatury w Wiedniu, które z założenia jest niemieckojęzyczne, do wiadomości w innych językach użytkownik uzyskuje dostęp na tablecie. Muzeum Pana Tadeusza proponuje zaś paralelną opowieść dla osób niewidomych i niedowidzących korzystająca jednocześnie z multimedialnych i materialnych technologii informacyjno-komunikacyjnych.

Materialność historycznoliterackich artefaktów uzupełniona zostaje również o to, co wirtualne, przez materiały przygotowane w formie dźwiękowej, wizualnej, grywalnej multimedialnej. Uwaga zwiedzającego zostaje zaabsorbowana przez zróżnicowane bodźce. W muzeum tradycyjnym dominowała wizualność i tekstualność. W nowym muzeum literackim, oprócz wspomnianych ekranów dotykowych i innych multimediów, uruchamianych poprzez wejście z nimi w interakcję; istnieją eksponaty, które można dotykać lub poruszać (np. sala w Muzeum Pana Tadeusza skonstruowana na kształt romantycznej biblioteki, prezentujacca reprinty oraz skany dzieł z epoki). Oglądanie i słuchanie nie są wymuszane na zwiedzającym, by je rozpoczać, należy uruchomić odpowiednią aplikację, wybrać jeden z wielu dostępnych na ekranach opisów, tematów, o których chce się posłuchać lub przeczytać.

Współczesne muzeum literackie proponuje model poznania, w którym istotną rolę odkrywa zaangażowanie zwiedzającego oraz podejmowanie przez niego wyborów, dokonywanie selekcji. Muzeum pozwala wybierać z dostępnego zbioru informacje, z którymi zapozna się zwiedzający, może on też decydować o sposobie zaznajamiania się z nimi (lektura tekstu na planszy/ekranie dotykowym; prezentacja multimedialna/film; audioguide; gra edukacyjna) — wiadomości udostępniane poprzez różne media bywają często względem siebie redundantne. Historia literatury proponowana przez muzeum nie jest ciagła 
narracją, przypomina raczej zbiór autonomicznych punktów, które łączone są ze sobą przez odbiorcę (a w szerszym sensie przez instytucję w obrębie, której się znajduja). Pominięcie danego eksponatu lub stanowiska, niewykorzystanie informacji nie zaburza procesu zwiedzania, a tym samym poznania. Muzeum o profilu historycznoliterackim proponuje w swoim obrębie odkrywanie - czy też współtworzenie - zróżnicowanych narracji, a jego strategia komunikacyjna nie polega na przekazywaniu. Tę historię literatury tworzy sieć punktów (w postaci eksponatu, stacji multimedialnej, urządzenia mobilnego czy całej sali), których zaktualizowanie skutkuje spersonalizowaną wizytą w muzeum, pojedyncza opowieścią historycznoliteracka. Pozwala to na indywidualizację poznania, zwiedzający nie jest biernym obserwatorem, ale współtworzy narrację muzealną dostosowaną do własnych upodobań (zgodnie z regułami kultury partycypacji).

Muzeum Literatury w Wiedniu proponuje swoim gościom tematyczne spacery historycznoliterackie, które nie odtwarzają głównej ścieżki zwiedzania zaproponowanej przez stałą ekspozycję. Muzeum można odkrywać, korzystając z elektronicznych wskazówek udostępnianych na tablecie według tematów-kluczy (m.in. młodzieżowa i dziecięca literatura austriacka oraz uchodźstwo i migracje), spacerując po przestrzeni w zróżnicowanych konfiguracjach (muzeum planuje stale zwiększać ilość dostępnych szlaków).

Muzea literackie, łącząc poetykę eksponatów z multimedialnym sposobem prezentacji, w różny sposób rozkładają metodologiczne akcenty. W Muzeum Pana Tadeusza to jeden literacki eksponat-oryginał ewokuje serię historycznoliterackich opowieści przede wszystkim na temat pierwszej połowy XIX wieku prowadzonych przez multimedia oraz przedmioty-kopie, rekonstrukcje, naśladownictwa itd. Literaturmuseum der Österreichischen Nationalbibliothek gromadzi dziesiątki literackich eksponatów-oryginałów i ich historii, z których następnie można układać liczne historie literatury (tematyczne, odwołujące się do danej formy literackiej, czasu, przestrzeni). Całość-muzeum składa się zaś na historię literatury austriackiej.

\section{Rękopis jako centrum historii literatury w Muzeum Pana Tadeusza}

Dla rękopisu ${ }^{12}$ Pana Tadeusza przeznaczona została w muzeum osobna, minimalistycznie zaprojektowana sala. Zajmuje ja jedynie autograf poematu — prezentowany w formie materialnej (za szybą w chłodzonej gablocie) oraz cyfrowej (w postaci skanu udostępnianego na ekranach dotykowych). Wystawa główna ukazuje kontekst polityczny, społeczny, biograficzny oraz literacki powstawania utworu ${ }^{13}$. Potrzeba opowiedzenia o tych okolicznościach konstytuuje muzealną historią literatury.

Sala prezentująca zabytek — rękopis poematu — nie jest tą, od której rozpoczyna się zwiedzanie. Pierwsze pomieszczenie zapoznawać ma odwiedzającego z wydarzeniami

12 „Autograf poematu w czystopisie i brulionie powstawał w latach 1832-1834. W skład rękopisu wchodza: zeszyt w miękkiej kartonowej oprawie, liczący 48 kart i ich fragmentów, zawierających czystopis księgi I-III oraz fragment IV; album liczący 91 kart zawierających w czystopisie księgi: IV-XII oraz w brulionie księgi X, XI, XII wraz z Epilogiem. W księgach VIII, XI i XII zdarzają się przygodne luki. 31,5 × $27 \mathrm{~cm}$ (album); $21 \times 15,5 \mathrm{~cm}$ (zeszyt)" (Muzeum Pana Tadeusza. Opis rekopisu b.r.).

Mimo że jest to muzeum poświęcone Panu Tadeuszowi, to nie stanowi ono zarazem biograficznego muzeum Adama Mickiewicza lub eksponatu — rękopisu Pana Tadeusza. Ten zabytek kultury prowokuje, by opowiadać, staje się przyczynkiem, zaczątkiem, by mówić o polskim romantyzmie, o historii literatury, o romantykach oraz o paradygmacie wytworzonym w XIX wieku, któremu przypisuje się długie trwanie jako ideowej formacji. 
politycznymi epoki, takimi jak m.in. brak polskiej państwowości, wojny napoleońskie, ruchy wyzwoleńcze (vide historia polityczna i społeczna w definicji historii literatury Teresy Walas). W gablotach oglądać można odzież z epoki, pamiątki wojskowe (np. szable), dziewiętnastowieczne portrety miniaturowe (eksponaty to zarówno oryginały, jak i rekonstrukcje). Prezentacji obyczajowości, konwenansów związanych z modą oraz życiem towarzyskim służą również przedmioty ilustrujące treść poematu. W jednej z kolejnych sal centralnie umieszczony został stół nakryty serwisem (ekspozycję wzbogacają inne media, takie jak film, opis dźwiękowy, gra wizualna), pozwalając zwiedzającemu zapoznać się z praktykowanym na polskich dworach zwyczajem ucztowania opisanym w Panu Tadeuszu. W pomieszczeniu zaaranżowanym na bibliotekę z epoki można znaleźć i czytać lub przeglądać książki zarówno w postaci materialnej (reprinty), jak i cyfrowej (skany zabytków) ${ }^{14}$. Romantycznego ducha oddaje też sala skonstruowana na wzór literacko-artystycznego salonu; nastrój uzyskany został tu poprzez dziewiętnastowieczną estetykę wnętrza oraz zawieszenie na ścianach portretów mecenasów - np. Salomei Bécu. Salon dínięeów romantycznych (bo taką nazwę nosi) przeznaczony jest dla kameralnych koncertów, stanowi również punkt na trasie zwiedzania. Milczący w nim na co dzień fortepian rekompensuja multimedialne stanowiska, przy których można posłuchać romantycznej muzyki lub obejrzeć na ekranach powstałe w XIX wieku wizualne dzieła sztuki. Każda część muzeum, nawet jeżeli dominują w niej inne narzędzia opowiadania (np. multimedialne), wyposażona jest w przedmioty zakorzeniające historię literatury w rzeczywistości/materialności.

Artefakt w muzeum jako materialny ślad działalności twórców czy ślad okoliczności powstawania literatury sprawiają, że w muzealnej historii literatury dowartościowany zostaje czynnik ludzki (Wehnert 2002: 69). Skutkiem muzealnej narracji zbierającej materialne ślady egzystencji (których opowieść przedłużona zostaje przez tekstowe, multimedialne i performatywne środki) jest zaakcentowanie biografii twórców, prywatności ich doświadczeń, a zarazem wpisanie ich życia oraz dzieła w kontekst epoki — tak dzieje się z Mickiewiczem i Panem Tadeuszem we Wrocławiu. Historia literatury jako muzeum nie jest więc jedynie historią utworów/arcydzieł, ale jej składniki to w głównej mierze historia polityczna i społeczna, biografia, historia idei, które ze względu na walory wystawiennicze reprezentujących je przedmiotów odgrywają w nim szczególną rolę. W dominacji tych czynników upatrywać można wątpliwości wysuwanych przez niektórych badaczy, czy literaturę i proces literacki da się w ogóle pokazać w formie wystawy, czy nie są to przedstawienia skrótowe, fragmentaryczne, czy nie ukazuje się raczej książki, cytatu, materialnej formy dzieła, nie zaś literatury, która pozostawać ma jednak wedle krytyków domeną tekstu (Wehnert 2002: 73-74).

\section{Powróz i trapery w Literaturmuseum der Österreichischen Nationalbibliothek}

Historia literatury w wiedeńskim muzeum ma przede wszystkim wymiar społeczny. Przedmiotem ekspozycji jest miejsce austriackiej literatury w kulturze od oświecenia po współczesność, jej sposób oddziaływania ze społeczną i polityczną rzeczywistością. Muzealna opowieść koncentruje się na reakcjach twórców na zmieniający się kontekst funkcjonowania literatury, wskazuje też sposoby rezonowania literatury z innymi dziedzinami sztuki, na to, w jak literatura wchodzi w interakcję z innymi sztukami.

14 Vide bibliografa w definicji Walas. 
W Literaturmuseum obowiązuje tematyczno-chronologiczny porządek narracji, jednostki opowieści nie są jednak stałe. Najwięcej miejsca poświęcono modernizmowi, który stanowi punkt ciężkości wystawy oraz — jeśli wierzyć jej wydźwiękowi — serce austriackiej kultury. Przestrzeń ekspozycyjna ${ }^{15}$ podzielona jest na różnej wielkości rozdziały (np. Im Schatten Napoleons, Das Dorf, Wien: Wege in die Moderne, Letzte Tage der Menschheit: der erste Weltkerieg, Expressionismus und Avantgarde itd.), których ramy wyznaczane są przez pozostałe tu po państwowym archiwum regały. Jednolity, powtarzający się w każdej z sal układ estetycznie kontrastuje z nowymi mediami oraz stwarza w muzeum porządek. Nie jest to jednak porządek przywodzący na myśl ten klasyczny, historyczny, linearny czy chronologiczny, regały buduja raczej wrażenie pewnego rodzaju zbioru, układu, który pozwala konstruować historycznoliteracką narrację. Dla przykładu, rozdział Die neue Frau dotyczy literackiego kontekstu zmieniających się praktyk kulturowych związanych z rolami kobiet na początku XX wieku. Historia społeczno-polityczna zarysowana zostaje przez krótką notę punktująca zjawiska-klucze, zjawiska-symbole, takie jak chociażby: I wojna światowa, kres mieszczańskiego modelu rodziny, wzrost niezależności kobiet oraz popularność krótkich fryzur u pań. Do tekstowej charakterystyki dołączają fotografie pisarek i żurnalistek, w gablocie prezentowany jest np. egzemplarz książki z 1928 roku autorstwa Meli Hartwig Ekstasen. Nouvellen oraz jej korespondencja. Zaintrygowany postacia pisarki i aktorki zwiedzający może przeczytać dostępny na muzealnym tablecie komentarz Bernharda Fetza, który podkreśla aspekt perwersji w jej twórczości oraz zestawia Hartwig m.in. z Virginią Woolf i Michelem Houellebecqiem. Górne półki regałów w części Die neue Frau zajmują plansze imitujące kształtem książki, na których grzbietach wypisane są tytuły znaczących dla tego okresu historii literatury. Zostały wymienione, by wskazać publikacje, które nie stały się głównym przedmiotem ekspozycji (nie zawsze ze względu na znaczenie dla danego momentu literackiego, ale np. z powodu braku eksponatów unaoczniających teksty).

Eksponaty wydają się bowiem w Literaturmuseum pełnić szczególną rolę. Wystawa gromadzi przede wszystkim dokumenty i zabytki piśmiennicze: manuskrypty, listy, notatki, historyczne edycje dzieł, okładki książek. Przedmioty te wydają się zbliżać zwiedzającego do materii tekstu, do momentów jego powstawania, tworzenia ${ }^{16}$, pozostałe zaś artefakty ukazują, jak literatura wiąże się z życie codziennym i społecznym. Eksponaty przedłużaja poznanie w sferze percepcyjnej oraz mają zaangażować odbiorcę emocjonalnie. Cześć z nich oddziałuje jednak z pewnością na zasadzie zbioru Wunderkammer i wywołać ma efekt zaskoczenia. Stanowia one ludyczny element ekspozycji. W Literaturmuseum ogladać można trapery Petera Handkego (w rozdziale poświęconym podróżom od austriackiego oświecenia po współczesność), opakowanie papierosów Jonny z 1928 r. (nazwa została zainspirowana popularna w owym czasie, krytykowana przez NSDAP opera Jonny spielt auf Ernsta Kreneka), egzemplarz akt spalonych 15 lipca 1927 roku w Wiener Justizpalast. Przedmiotem, który wydaje się mieć coś z makabreski, jest znajdująca się w rozdziale poświęconym tematyce wsi lina do wycieleń (Kälberstrick) podarowana muzeum przez Josefa

15 Dwa piętra Grillparzerhaus poświęcone są historii literatury austriackiej, trzecie piętro to wystawy czasowe, komentarze, prezentacje najnowszej literatury.

16 Jednej rozdział ekspozycji w Literaturmuseum (Schreibprozesse [Proces pisania/tworzenia]) poświęcony jest problemowi, jak powstaje tekst. 
Winklera. Powróz stanowi lejtmotyw jego twórczości i miał zostać znaleziony w stodole, w której rozegrało się kluczowe dla Winklera doświadczenie — odebranie sobie życia przez dwójkę siedemnastolatków za pomocą wskazanej liny.

Umieszczenie eksponatu w muzeum literackim służy ponownemu połączeniu literatury z subiektywnymi okolicznościami rozumienia tekstu (Fetz 2015: 16). Autorzy katalogu gromadzącego przedmioty pokazywane w Literaturmuseum twierdza, że to nie różnorodność medialna sama w sobie decyduje o odmienności tzw. nowych muzeów literackich od tych klasycznych (gromadzących pamiątki po pisarzach oraz naśladujące je atrapy itd.). O swojej instytucji piszą jako o miejscu umożliwiającym patrzenie (Schau-Museum), słuchanie (Hör-Museum), ukazującym różnorodność językową oraz medialną, a także powiązanie literatury z innymi sztukami. Na wystawie umieszczone są stacje, przy których odsłuchać można fragmentu wykonywanej prozy, niektóre passusy czytywane są przez autorów tekstów z dialektalną wymową. Literatura to nie tylko zapis, pismo, ale również głos - w takie problemy wikła się nowe muzeum literatury, w którym celem staje się doświadczenie, możliwość doznawania literatury i jej historii przez różne formy i media. To, co historyczne, nabiera znaczenia aktualnego w tak zaprojektowanej muzealnej przestrzeni, a eksponaty nie są relikwiami, ale tym, co uobecnia przeszłość.

\section{Muzealna historia literatury}

Muzealna historia literatury w przeciwieństwie do akademickiego dyskursu (np. syntezy historycznoliterackiej) — którego znamionami są racjonalność i analityczny wywód — proponuje model poznania oparty na zaangażowaniu zmysłów (możliwość słuchania, patrzenia, czytania, a nawet dotykania), model przynoszący tzw. wiedzę ucieleśniona. Muzeum Literatury w Wiedniu reklamuje się hasłem wymieniającym czynności, które można podjąć w jego przestrzeni: Lesen, bören, sehen und staunen Sie! [Czytajcie, słuchajcie, oglądajcie, zadziwcie się!] (Literaturmuseum b.r.). Do tej wyliczanki można by dodać jeszcze polecenie dotykania, grania i tworzenia ${ }^{17}$, wymieniając wszystkie dostępne formy aktywizowania zwiedzającego w obrębie współczesnego muzeum literatury.

Zarysowany sposób wprowadzenia zwiedzającego w muzealną przestrzeń przypomina próbę bazowania na zaangażowaniu, od którego muzeum nowoczesne starało się odchodzić. Współczesne muzeum, bazując na zmysłowym, emocjonalnym i afektywnym zaangażowaniu odbiorcy, wydaje się sięgać do proweniencji tej instytucji wywodzącej się z gabinetów kuriozów i ich zasady zaskoczenia/zadziwienia (Bennett 1995: 8-20). Przestrzeń muzealna uporządkowana i zracjonalizowana w XIX wieku, stanowiąca naukowa przestrzeń reprezentacji, dziś konstruowana jest znów tak, by pobudzać zainteresowanie na zasadzie afektywnej (choć projektuje odmienne afekty niż oszołomienie). Wynika to pośrednio z tego, że muzeum literackie stanowi dziś również rodzaj produktu turystycznego i chcąc konkurować z innymi formami rozrywki, prócz odpowiednich strategii edukacyjnych, przyjmuje te marketingowe.

Muzealna historia literatury odpowiada na pytanie, jak wykorzystać w narracji historycznej przedmioty, literackie pamiątki i dokumenty, jak materialnie opowiadać o przeszłości literatury. Zarysowana forma muzeum jako historii literatury, angażująca odbiorce poprzez doświadczenie materialności muzealnych obiektów oraz na poziomie użytkowania

17 Czyli również spotkania i warsztaty edukacyjne, wykłady, zajęcia dla dzieci w obszarze muzeum. 
interaktywnych multimedialnych materiałów, jednocześnie oddziałująca na fizys i ratio zwiedzającego, to historiografia literatury, która ma szansę wyjść poza akademię. Nie tylko łączy rozrywkę z edukacja, ale angażuje całość człowieka w poznanie. Próba odpowiedzi na pytanie, czemu służy taka forma muzeum (poza popularyzacją wiedzy) — np. w planie politycznym lub etycznym - wymaga refleksji nad tym, czemu służy tak skonstruowana instytucja (jej multimedialność, performatywność, materialność itd.) oraz jaki jest wydźwięk ideologiczny poszczególnych muzeów.

Muzeum Pana Tadeusza w promocyjnym folderze definiowane jest jako „miejsce w którym łączy się historia i współczesność” (...tam, gdzie historia spotyka się ze współczesnościa b.r.: 1), jego misją jest zaś „pokazanie rangi dzieła Adama Mickiewicza w zmieniającej się rzeczywistości historycznej i kulturalnej Europy na przestrzeni ostatnich dwustu lat" (...tam, gdzie historia... b.r.: 1). Muzeum, posługując się językiem współczesnej kultury (popularnej), próbuje opowiedzieć polską historię literatury pierwszej połowy XIX wieku. Jednocześnie stara się umiejscowić we współczesnej kulturze znaczenia eksponatu — rękopisu Pana Tadeusza — oraz samego dzieła Mickiewicza. Muzeum Pana Tadeusza bezpośrednio formułuje swój cel i wydźwięk, w ostatnich salach, ukazując trwanie przesłania dzieła Mickiewicza oraz romantycznego paradygmatu ideowego w twórczości i biografii współczesnych Polaków - przedstawiając utwory Andrzeja Wajdy oraz włączając w swoją narrację ekspozycję dotyczącą życia Jana Nowaka-Jeziorańskiego oraz Władysława Bartoszewskiego, którzy ofiarowali muzeum wybrane eksponaty. To zakończenie wystawy zamyka/ogranicza pola interpretacyjne muzeum, pokazując, że cała prowadzona w jego obrębie narracja dotyczy wolności (i jej zakorzeniania w romantycznych ideach) w polskiej kulturze i historii.

Wydźwięk ekspozycji w Muzeum Literatury w Wiedniu nie jest tak jednoznaczny. Pytania podstawowe o to, czym jest muzeum literackie, literatura oraz Austria pozostaja otwarte, komplikuje je różnorodność etniczna, wielokulturowość dziedzictwa (mit habsburskiej monarchii) oraz multimedialność instalacji. Sama zaś instytucja w materiałach promocyjnych stara się podkreślać heterogeniczność swoich zbiorów oraz otwartość na interpretacje ${ }^{18}$.

Analizowane muzea nie stanowią jedynie miejsc historycznej pamięci, oba proponuja szereg wystaw czasowych, spotkań tematycznych, dyskusji oraz wydarzeń, dla których pretekst stanowia posiadane przez nie zbiory. Obie instytucje wspierane są zapleczem naukowym (odpowiednio przez Zakład Narodowy im. Ossolińskich oraz przez Österreichische Nationalbibliothek), jednak ich narrację można scharakteryzować jako popularna, przygotowana przez ekspertów dla szerokiego grona - miłośników literackiej przeszłości, uczniów i studentów, fascynatów literatury. Podobne środki wykorzystane są innych celach ideologicznych. Wydaje się, że w Muzeum Pana Tadeusz̨a nowoczesne środki prezentacji służą rozrywce, skoncentrowane są na zabawie, uatrakcyjniają konserwatywny

18 „Erkunden Sie die österreichische Literatur, ihre Themen, Formen und Zeitgeschichten; ihre Buntheit, Internationalität und Mehrsprachigkeit; ihr Verhältnis zu anderen Künsten: zu Film, Musik, Malerei und Grafik; ihre Schauplätze und die Orte des literarischen Lebens: vom städtischen Kaffeehaus über den Wiener Prater und das Bergdorf bis zur indonesischen Insel Sumatra" [Zapoznajcie się Państwo z austriacką literatura, jej tematami, formami i historią współczesną z jej różnorodnością, międzynarodowością i wielojęzycznością; z jej stosunkiem do innych sztuk: do filmu, muzyki, malarstwa i grafiki; z miejscami jej akcji oraz z miejscami literackiego życia: od miejskich kawiarni przez Wiedeń Prater i Bergdorf aż do indonezyjskiej wyspy Sumatra] (Literaturmuseum b.r.). 
przekaz historycznoliteracki dotyczący dzieła Mickiewicza i znaczenia romantycznego paradygmatu dla polskiej kultury ${ }^{19}$. Literaturmuseum próbuje aspekt ludyczny spersonalizować, proponując wiele ścieżek zwiedzania dostosowanych do preferencji i gustu odbiorcy. Jednocześnie brak w muzeum jednej scalającej, wielkiej narracji, multietniczność i multikulturowość stanowią podstawę ekspozycji, choć należy pamiętać, że stanowić ma ono publiczny znak, ukazywać znaczenie światowe literatury austriackiej (Fetz 2015: 15). Oba muzea próbują opowiedzieć o mitach — wrocławskie o Panu Tadeuszu jako o akcie twórczego oporu, o symbolice poematu i jego znaczeniu dla polskiej historii, zaś muzeum wiedeńskie opowiada o micie monarchii habsburskiej.

\section{Bibliografia}

...tam, gdzie historia spotyka sie ze wspótczesnościa (b.r.), Muzeum Pana Tadeusza, Ossolineum, Wrocław.

Benjamin Walter (1996), Dzieło sztuki w dobie reprodukcji technicznej oraz. Mała historia fotografii [w:] tegoż, Anioł historii, eseje sælkice fragmenty, tłum. H. Orłowski, Wydawnictwo Poznańskie, Poznań.

Bennett Tony (1995), The Birth of the Museum. History, Theory, Politics, Routlege, London-New York.

Böhmer Sebastian (2015), Was bedeutet die Materialität der Literatur für die Literatur(-ausstellung)? Ein Versuch [w:] Zwischen Materialität und Ereignis. Literaturvermittlung in Ausstellungen, Museen und Archiven, hrsg. B. Hochkirchen, E. Kollar, transcript, Bielefeld.

Bücher. Bernhard Fetz. (Hrsg.) Das Literaturmuseum (b.r.), ,JJung und Jung”, http://jungundjung.at/ content.php?id=2\&b_id=224 [dostęp: 12 grudnia 2016].

Das Literaturmuseum. 101 Objekte und Geschichten (2015), hrsg. Bernhard Fetz, Jung und Jung, Salzburg/Wien.

Folga-Januszewska Dorota (2008), Muzeum: definicja i pojecie. Caym jest muzeum dzisiaj?, „Muzealnictwo", nr 49.

Głowiński Michał (2002), Muæeum literackie [hasło], Słownik terminów literackich, red. M. Głowiński i in., Zakład Narodowy im. Ossolińskich, Wrocław.

19 Choć należy wspomnieć o próbach burzenia tak jednoznacznej narracji, przykładem jest sala, w której toczy się multimedialna debata (wideo) o znaczeniu Mickiewiczowskiego poematu. Innym przykładem może być sala inscenizowana na dziewiętnastowieczną karczmę, w której można wziąć udział w ankiecie dotyczącej migracji (tematyka migracji/emigracji ukazana zostaje jako aktualny problem). 
Henning Michelle (2006), New Media [w:] Companion to Museum Studies, red. S. MacDonald, Wiley-Blackwell, Chicester.

Käuser Andreas (2009), Ist Literatur ausstellbar? Das Literaturmuseum der Moderne. Anmerkungen zur Konzeption und Diskussion, „Der Deutschunterricht“ 61, H. 2.

Kostyrko Teresa (2006), Dzieło sz̨tuki w muzeum i jego aura [w:] Muzeum sz̧tuki. Od Luwru do Bilbao, red. M. Popczyk, Muzeum Śląskie, Katowice.

Lachman Magdalena (2006), Muqeum w perspektywie literackiej i literaturoznawczej [w:] Muzeum sztuki. Od Luwru do Bilbao, red. M. Popczyk, Muzeum Śląskie, Katowice.

Literaturmuseum (b.r.), „Österreichische Nationalbibliothek”, https://www.onb.ac.at/museen/ literaturmuseum/ [dostęp: 12 grudnia 2016].

Muzeum Pana Tadeusza. Opis rękopisu (b.r.), „Ossolineum.pl”, Zakład Narodowy im. Ossolińskich, https://ossolineum.pl/index.php/muzea/muzeum-pana-tadeusza/ [dostęp: 2 grudnia 2016].

Olsen Bjornar (2010), Kultura materialna po tekście: pryywracanie obecności rzeczom [w:] Teoria wiedzy o przeszłości na tle wspótczesnej humanistyki. Antologia, red. E. Domańska, Wydawnictwo Poznańskie, Poznań.

Polskie muz̧ea literackie. Præewodnik, opr. i red. W. Koradczuk, L. Ujazdowska, Muzeum literatury im. Adama Mickiewicza, Warszawa.

Rosenstone Robert A. (2007), Space for the Bird to Fly [w:] Manifestos for History, eds K. Jenkins, S. Morgan, A. Munslow, Routledge, London-New York.

Schweiger Hannes (2016), Rozmowa przeprowadzona przez Joanne Maj 21 grudnia 2016, Dresden. Walas Teresa (1993), Czy jest możliwa inna historia literatury?, Universitas, Kraków.

Wehnert Stefanie (2002), Literaturmuseen im Zeitalter der neuen Medien. Leseumfeld - Aufgaben Didaktische Konzepte, Verlag Ludwig, Kiel.

Ziębińska-Witek Anna (2015), Muzea wobec nowych trendów w bumanistyce. Refleksje teoretyczne, „Historyka. Studia Metodologiczne”, T. 45. 